Научная статья

УДК 80

DOI 10.18101/2306-630X-2020-2-20-26

\title{
СОЦИОЛИНГВИСТИЧЕСКИЙ КОНФЛИКТ В НОРВЕГИИ: БУКМОЛ ИЛИ НЮНОРСК?
}

\author{
(C) Бестолкова Галина Васильевна \\ кандидат филологических наук, преподаватель, \\ Московский государственный университет имени М. В. Ломоносова \\ Россия, 119991, г. Москва, Ленинские горы, 1 \\ ilfactotumdelluniversita@mail.ru
}

\begin{abstract}
Аннотация. Отношение к многоязычию претерпело значительные изменения во всем мире в результате широкого распространения либеральных идей во второй половине $\mathrm{XX}$ в. В настоящее время особое значение имеет опыт отдельных стран, в которых многоязычие закреплено законодательным образом и накоплен богатый опыт межкультурных и межъязыковых отношений. В статье рассматриваются исторические причины возникновения двуязычия в стране и дается характеристика современной социолингвистической ситуации в Норвегии. Путь Норвегии к двуязычию лежал через борьбу за национальную независимость и самоопределение. Страна предприняла попытку создания своего языка, которая привела к созданию двух норвежских языков - датско-норвежского (букмол, bokmål) и новонорвежского (нюнорск, nynorsk). Развитие букмола и нюнорска переросло в открытое противостояние, языковую борьбу, и эта борьба остается до сих пор незавершенной, одним из самых значительных ее результатов является языковой раскол культуры Норвегии.

Ключевые слова: Норвегия; социолингвистический конфликт; букмол; нюнорск; риксмол; ландсмол; самнорск.
\end{abstract}

\section{Для цитирования}

Бестолкова Г. В. Социолингвистический конфликт в Норвегии: букмол или нюнорск // Евразийство и мир. 2020. № 2. С. 20-26.

\section{Исторические предпосылки появления двуязычия в Норвегии}

Определяющим для лингвистической ситуации в Норвегии является историческое развитие страны, которая находилась в политической зависимости от Дании более 400 лет, и датский язык в разные периоды этих столетий играл весьма разную роль. В 1397 г. при заключении Кальмарской унии датский король получил под свое начало Норвегию с входившей в ее состав Исландией и Швецию с Финляндией, так Дания стала великой европейской державой [1].

Одним из главных последствий колонизации Норвегии стала гибель норвежского письменного языка, который постепенно заменил датский. Столь широкому распространению датского языка на территории Норвегии способствовала Реформация, которую проводила датская церковь. И как следствие, письменным языком Норвегии, становится датский, тогда как норвежский сохраняется преимущественно как разговорный язык. При этом в городах складываются смешанные говоры, лексика и морфология которых были в основном датскими, а фонетика и синтаксис- 
норвежскими. В сельской местности население продолжает говорить на соответствующих диалектах, которые, сохраняя преемственность с древненорвежскими, в то же время претерпевают существенные изменения, и в XVI в. их фонетическая и морфологическая система приобретает вид, во многом соответствующий тому, что мы находим в современных диалектах, особенно архаичных. Вследствие этого между письменным датским и разговорным норвежским языком образуется значительный разрыв.

Процесс создания общенационального норвежского языка

После обретения Норвегией независимости от Дании в 1814 г. встал вопрос о создании общенационального норвежского языка. Страна разделилась на два лагеря: одни стремились «онорвежить» датский язык и в результате на свет появился риксмол (riksmål, «государственный язык»); другие же задались целью создать новый язык, на основе диалектов населения сельских регионов Норвегии, что помогло создать ландсмол (landsmål, «сельский язык»).

Представители первого направления призывали провести «норвегизацию» литературного языка, роль которого выполнял датско-норвежский язык (dansknorsk), адаптировав орфографию и синтаксис к норвежскому использованию и заменив там, где это было возможно, иностранные слова норвежскими эквивалентами. В 1890 г. эта форма литературного языка получила название риксмол (riksmål).

Лидером данного направления являлся норвежский филолог Кнуд Кнудсен (Knud Knudsen, 1812-1895). К. Кнудсен был первым адъюнкт-профессором в Драммене и как преподаватель он заметил, что у студентов возникли трудности с написанием на датском языке, когда они говорили на норвежском языке, тогда Кнудсен пришел к выводу, что письменный язык должен быть изменен в соответствии с общепринятой речью. Стремясь произвести изменения в языке в кратчайшие сроки, он выдвинул несколько реформ, работающих на датском письменном языке [2]. Наиболее полное обращение к этому предмету можно найти в его труде «Unorsk og norsk, eller Fremmedords avlösning» (1881).

Основоположником второго направления был филолог-самоучка Ивар Осен (Ivar Aasen, 1813-1896), который создал искусственный, синтезированный язык из различных диалектных форм, отдавая предпочтение их архаичным чертам [3]. В самом названии нового языка «лансмол» (landsmål), которое можно перевести как «язык страны» или «сельская речь», отражена идея создания народного норвежского языка. Надо отметить, что идея создания лансмола, отвечала общественной потребности в обретении независимости Норвегии от иностранного влияния.

Несмотря на то, что И. Осен не имел образования, качество его лингвистических работ можно считать крайне высоким. К примеру, «Словарь норвежского народного языка» (Ordbog over det norske Folkesprog (1850)), подготовленный Осеном, куда входило более 25000 слов, выдающийся норвежский историк Петер Андреас Мунк (Peter Andreas Munch, 1810-1863) назвал «национальным шедевром». Следует также отметить, что в 1848 г. И. Осен издал книгу «Грамматика норвежского народного языка» (Det norske Folkesprogs Grammatikk), а первые тексты на лансмоле были изданы в его книге «Образцы деревенского языка в Норвегии» (Prøver af Landsmaalet i Norge, 1853). Идея создания ландсмола нашела поддержку 
партии левых (Venstre), пришедшей к власти в 1884 г. и уже в 1885 г. принимается likestillingsvedtaket (постановление о равноправии), заключающееся в том, что ландсмол уравнивается в правах с риксмолом. В стране назревала языковая реформа. Одним из ее наиболее активных пропагандистов был профессор, собиратель норвежского фольклора Молтке Мy (Moltke Moe, 1859-1913), ратовавший за языковое объединение в стране.

Борьба сторонников риксмола и ландсмола особенно усилилась на рубеже XIX и XX вв. [4]:

- В 1899 г. в университете Кристиании была учреждена кафедра ландсмола. Ее возглавил известный лингвист Мариус Хегстад (Marius Hægstad, 1850-1927). По традиции при вступлении в должность профессор должен был прочитать публичную лекцию. М. Хегстад выбрал тему «Происхождение норвежских народных говоров» и прочитал лекцию на ландсмоле.

- В 1909 г. сторонники риксмола объединяются в языковое сообщество "Riksmälsforbundet" (сообщество сторонников государственного языка), чтобы совместными усилиями способствовать укреплению позиций риксмола в стране и противостоять расширению сферы использования ландсмола.

В период с 1907 по 1938 г. оба варианта норвежского языка претерпели несколько языковых реформ:

- Реформы ландсмола $(1907,1910,1917,1938)$ приблизили его норму к диалектам Восточной Норвегии, которая является наиболее населенной частью страны.

- Реформы риксмола $(1907,1917,1938)$ способствовали замене датской орфографии норвежской. Наиболее радикальная реформа (1938) сделала обязательными сугубо разговорные формы, которые многими считались и продолжают считаться нелитературными.

Цель всех этих реформ была благой - сблизить оба варианта норвежского языка с перспективой их дальнейшего полного сближения.

Следует отметить, что политику сближения риксмола и ландсмола поддерживало созданное в 1916 г. теологом и педагогом Эйвиндом Берггравом (Eivind Berggrav, 1884-1959) движение за возрождение восточнонорвежских диалектов, получившее название «Восточное восхождение» (0stlandsk Reisning). Основная идея движения заключалась в том, что для создания действительно общенорвежской письменной литературной нормы необходимо было включить в нее элементы всех представленных в стране диалектов. По мнению сторонников движения, восточным диалектам уделялось недостаточно внимания, так как они находились «под гнетом престижа» городского говора столицы и имели низкий социальный статус [5].

Более того, И. Осен изначально создавал ландсмол из западнонорвежских диалектов, а следовательно, для того чтобы сделать его подлинным общенорвежским языком (самнорск (samnorsk)), нужно было ввести в него элементы восточных диалектов. Только такой общенорвежский национальный язык мог эффективно противостоять датско-норвежскому, на котором продолжали писать и говорить горожане.

В 1971 г. в стране был создан Совет по языку (Det Norske Språkråd), призванный вести нормирование языка и терминологическую работу. Совет включал в себя две секции, каждая из которых была направлена на работу с одним из ва- 
риантов норвежского языка (риксмола или ландсмола). Решения Совета не были обязательны к исполнению и, по сути, это были рекомендации, которые должны были утверждаться Министерством культуры. К сожалению, все действия Совета по языку носили примирительный характер и ставили своей целью уравнять «элитарную» и «народную» языковую культуру страны. Значительные усилия Совет по языку тратил на борьбу с англицизмами, так как в послевоенный период 80-90\% заимствований в норвежский язык пришло из английского, это общая тенденция и норвежский язык не стал исключением.

Таким образом, итогом жарких дискуссий о судьбе национального языка в Норвегии стало уравнивание в правах двух вариантов литературного языка - рисксмол и ландсмол. Впоследствии риксмол был переименован в букмол (bokmål, «книжный язык»), а ландсмол — в нюнорск (nynorsk, «новонорвежский язык»).

\section{Современная социолингвистическая ситуации Норвегии}

Как уже отмечалось ранее, в настоящее время ни в одной европейской стране нет такого уникального лингвистического явления, как в Норвегии. В стране с населенностью 4.5 млн жителей есть два официальных языка: букмол (bokmål) - дано-норвежский язык, основанный на датской литературе и подвергшийся процессу «онорвегизации», и нюнорск (nynorsk) - новонорвежский язык, созданный из старых диалектов норвежского и древнескандинавского языков.

Норвежская газета «Афтенпостен» так описала современную языковую ситуацию в стране: «Два языковых кода для народа, составляющего жалкие 4,5 миллиона» ${ }^{1}$.

Несмотря на то, что по действующему законодательству страны, оба языка уравнены в правах, в действительности же данные языки занимают далеко не равноценные позиции в современном норвежском обществе: $88 \%$ населения страны говорят на букмоле и только $12 \%$ говорят на нюнорске (рис.)

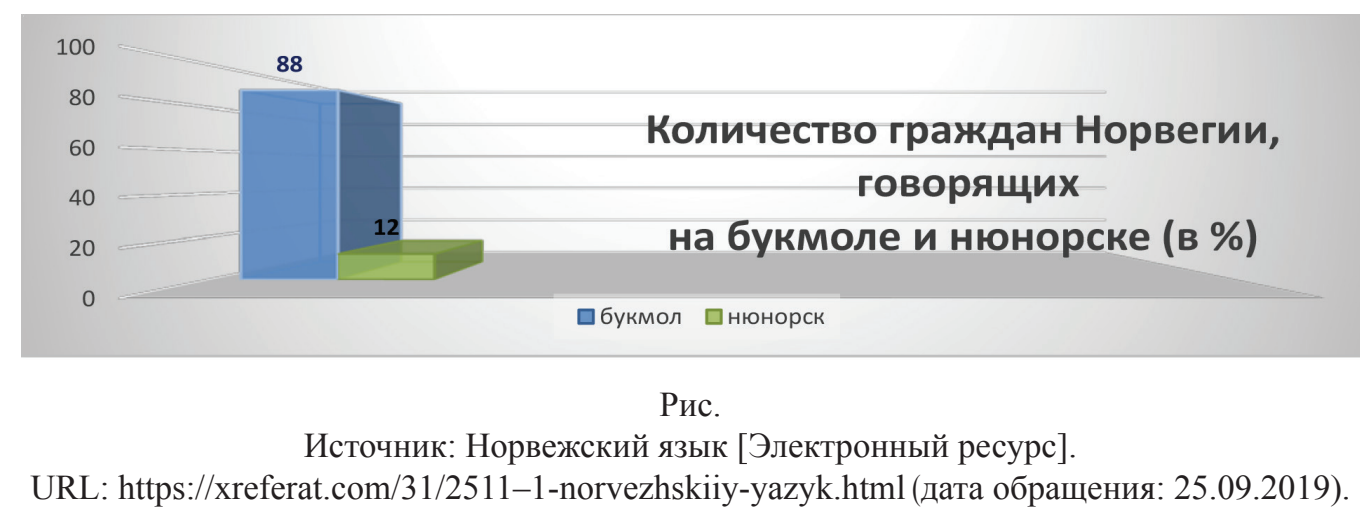

Более того, 90\% печатной продукции выходит на букмоле. На радио и телевидении также господствует букмол, так как $75 \%$ времени вещание ведется на данной версии норвежского языка. В школе обучение ведется на двух языках, но и в данном случае предпочтение отдается букмолу. Нюнорск ученики, обучающиеся на букмоле, изучают лишь пассивно. Государство пытается изменить ситуацию, используя язы-

\footnotetext{
${ }_{1}$ «Aftenposten», 2002. [Электронный ресурc]. URL: https://www.aftenposten.no (дата обращения: 30.06.2019).
} 
ковую политику, принципы которой мы рассмотрим далее. Согласно Министерству по делам культуры и церкви, главной стратегической целью языковой политики Норвегии является «... обеспечивать норвежский язык полноценным статусом и использованием во всех областях норвежского общества» ${ }^{1}$. Все законы, официальные распоряжения и т.п. издаются в двух вариантах. По действующему законодательству лицу, обращающемся в официальные инстанции, положено отвечать на том варианте норвежского языка, которым это лицо пользуется. Письменный «билингвизм» призван укреплять языковое сознание населения: каждый текст является результатом языкового выбора, а выбранная форма может интерпретироваться как выражение идентичности автора.

Таким образом, государственная языковая политика Норвегии стремится продвигать одновременно и языковое сообщество, и языковое разнообразие.

Важными принципами норвежской государственной языковой политики являются:

1) главный и общенациональный язык страны - норвежский;

2) норвежский язык является общественной опорой государства;

3) необходимо принимать особые меры для того, чтобы нюнорск более реально приравнивался к букмолу;

4) государство стремиться к осуществлению правильной и понятной речи;

5) у всех граждан есть право на язык, на развитие и приобретение норвежского языка (букмола и нюнорска), на развитие и использование родного языка или языка национального меньшинства².

Следует отметить, что норма как нюнорска, так и букмола в настоящий момент настолько многовариантна, что может считаться нормой с большой натяжкой, поэтому государство стремится к формированию правильной и понятной языковой нормы норвежского языка, но вместе с тем государство с помощью своей языковой политики допускает употребление почти всех мыслимых форм норвежского языка, что приводит к расшатыванию и без того нечеткой языковой нормы.

Более того, в докладе Правительства Норвегии, посвященном языковому развитию страны, в пункте «Основные функции», говорится, что: «Язык является основой для всех нас. Наша идентичность и наше представление о самих себе в значительной степени привязаны к языку» ${ }^{3}$. Большая часть параграфа посвящена именно этой функции языка и совсем мало сказано о коммуникативной [7], что свидетельствует о том, что для носителей малых языков на первый план выходит функция отражения языком национальной, региональной, локальной и индивидуальной идентичности, а не коммуникативная функция языка, чему служит свидетельством современная социолингвистическая ситуация в Норвегии.

\footnotetext{
${ }^{1}$ Министерство по делам культуры и церкви Норвегии: отчет № 35 (2007-2008) // Норвежская языковая политика [Электронный ресурс]. URL: https://www.regjeringen.no/no/dep/kd/ id586/ (дата обращения: 07.05.2019).

2 Там же.

${ }^{3}$ Mål og meining, 2009. [Электронный pecypc]. URL: https://www.regjeringen.no/globalassets/ upload/kkd/kultur/sprakmelding_kortversjon_feb2009.pdf (дата обращения: 22.07.2019).
} 
Бестолкова Г. В. Социолингвистический конфликт в Норвегии: букмол или нюнорск?

\section{Заключение}

Проведенное исследование позволяет сделать следующие выводы:

- Становление нюнорска и букмола происходило на фоне, с одной стороны, жесткой политической борьбы, сопровождавшей выходом Норвегии из Кальмарской унии с Данией, с другой - поиска национального самосознания и языка.

- На судьбах норвежского языка отразилась также политическая борьба, которая на протяжении новейшей истории велась между ведущими партиями страны- Рабочей партией Норвегии и ее правыми буржуазными оппонентами. Именно Рабочая партия ратовала за сближение обоих государственных языков и сделала варианты языка объектами языкового планирования. Главной своей целью языковые радикалы считали создание единого языка, так называемого самнорска (samnorsk). Однако слишком пристальное внимание политиков к языку принесло норвежскому языку немало бед, усилия по созданию единого национального языка не увенчались успехом.

Таким образом, развитие букмола и нюнорска, изначально имевших различные социокультурные основания, переросло в открытое противостояние, языковую борьбу и эта борьба остается до сих пор незавершенной, одним из самых значительных ее результатов является языковой раскол культуры Норвегии.

Лuтература

1. Стеблин-Каменский М. И. История скандинавских языков. М.; Л.: Академия наук CCCP, $1953.340 \mathrm{c}$.

2. Haugen E. Language Conflict and Language Planning: The case of modern Norwegian. Cambridge: Harvard University, 1966. 396 p.

3. Hoel O.L. Nynorsken // Ivar Aasen (CD-ROM). Oslo: Det Norske Samlaget, 1997 [Электронный pecypc]. URL: http://www.aasentunet.no/default.asp7menuH250 (дата обращения: 18.05.2019).

4. Берков В. П. История норвежского языка. СПб.: Изд-во СПбГУ, 2012. 155 с.

5. Юченкова А. К. Плюрализм нормы норвежского литературного языка. М.: Изд-во Моск. гос. ун-та им. М. В. Ломоносова, 2008. 127 с.

6. Ливанова А.Н. Языковая ситуация в Норвегии // Материалы XXXII Междунар. филол. конф. СПб., 2003. С. 10-14.

7. Шенявская Т. Л. Норвежский язык «датского периода» // Скандинавская филология. 2007. Вып. ІХ. С. 268-275.

\section{SOCIOLINGUISTIC CONFLICT IN NORWAY: BOKMÅL OR NYNORSK?}

Galina V. Bestolkova

Cand. Sci. (Phil.),

Lecturer of Foreign Languages and Regional Studies Faculty

Lomonosov Moscow State University,

1 Leninskie Gory, Moscow 119991, Russia

ilfactotumdelluniversita@mail.ru 
Abstract. Attitude towards multilingualism has undergone significant changes throughout the world as a result of the widespread of liberal ideas in the second half of the 20th century. Nowadays, it is important to take into consideration the experience of individual countries, in which multilingualism is enshrined in law, and positive experience of intercultural and interlanguage relations.

The article analyzes the historical reasons for the emergence of bilingualism and presents a detailed description of the current sociolinguistic situation in Norway.

Norway's path to bilingualism lay through the struggle for national independence and self-determination. The country made an attempt to create its own language, that led to the creation of two Norwegian languages - Danish-Norwegian (Bokmål) and New Norwegian (Nynorsk). Development of Bokmål and Nynorsk has grown into an open confrontation, a language struggle, and this struggle still remains unfinished. One of its most significant results is the linguistic split of the Norwegian culture.

Keywords: Norway; sociolinguistic conflict; Bokmål; Nynorsk; Riksmål; Landsmål; Samnorsk.

Статья поступила в редакцию 01.10.2020; одобрена после рецензирования 30.11.2020; принята к публикации 11.12.2020. 